\title{
The Roles of Emotional Intelligence, Interpersonal Skill, and Transformational Leadership in Improving Construction Safety
}

Riza Yosia Sunindijo, (University of New South Wales, Australia)

Patrick X.W. Zou, (University of Canberra, Canberra, Australia)

\begin{abstract}
Due to the characteristics of the construction industry, human skills are essential for working with and through others in managing safety. Previous research has shown that emotional intelligence, interpersonal skill, and transformational leadership are human skill components that generate superior performance in today's workplace. The aim of this research is to investigate the influence of project management personnel's human skills (in terms of emotional intelligence, interpersonal skill and transformational leadership) on the implementation of safety management tasks and development of safety climate in construction projects. The structural equation modelling (SEM) method was applied to analyse the quantitative data collected via surveys and to establish interrelationship among the research variables. The results indicate that emotional intelligence is a key factor for developing interpersonal skill and transformational leadership, and for implementing safety management tasks which leads to the development of safety climate. This research also found that interpersonal skill is needed for becoming transformational leaders who contribute to the development of safety climate.
\end{abstract}

Keywords: Construction safety, Emotional intelligence, Human skills, Interpersonal skill, Safety climate, Safety management tasks, Transformational leadership

\section{Introduction}

The construction industry worldwide is notorious as being one of the most dangerous industrial sectors (Lingard and Rowlinson 2005; Safe Work Australia 2012). For example, in 2009-10, the incidence rate of claims was 19.9 claims per 1000 employees, much higher than the rate for all industries of 13 claims per 1000 employees. From 2008-2011, the industry's fatality rate is 4.26 fatalities per 100,000 workers, which is twice the national fatality rate of 2.23 (Safe Work Australia 2012). In 2012, several fatalities occurred within a short period of 12 months compelling the government to establish an enquiry to address safety issues on sites (ACT Government 2012).

There is an urgent need to search (and research) for new strategies and methods to improve construction safety performance in order to achieve the goal of zero harm (McGeorge and Zou 2013). Much research has been conducted in construction safety management, such as safety risk management, safety management system framework and measurement, safety in design, building information modelling (BIM), and the return on investment of safety (Zou and Sunindijo 2013). However, modern technology, automation, and safety management system are considered to be inadequate to further improve safety performance. This is because no matter how automated a production process or complex a management system is, people still control production and must intervene when unplanned events occur. Unfortunately, people are prone to errors, and human errors have become a part of daily activities. Furthermore, due to its labour-intensive characteristic, human errors have greater impacts on construction safety 
(Lingard and Rowlinson 2005). Therefore, focusing on the human side of safety and human error mechanism is deemed as a feasible and practical way to improve safety (Reason 1990).

Project management personnel, such as construction managers, project managers, site managers, engineers, site supervisors, and safety personnel, who form an important part of the "human side of safety", play an important role in improving construction safety. For example, management commitment has frequently been considered as a key factor for successful safety programs (Lingard and Rowlinson 2005). Better safety performance can be expected when site managers and supervisors engage workers in regular safety talks (Langford et al. 2000). Furthermore, project staff can use political skill to develop safety climate (Sunindijo and Zou 2012), while project management personnel have an important and ongoing safety leadership role to play in improving safety performance (Dingsdag et al. 2006).

The aforementioned safety roles and responsibilities necessitate project management personnel to have sufficient skills. Working with people is inevitable in construction projects due to the involvement of various stakeholders and its labour-intensive work nature. This fact demonstrates the importance of human skills to work with and through others during safety implementation. In other words, most on-site construction activities are undertaken by labourers, through the management and supervision of foremen and site managers, which in turn are under the management of project and construction managers who oversee the whole project. Previous studies have shown that emotional intelligence, interpersonal skill, and transformational leadership are indispensable human skill components in today's dynamic workplace (Bass and Riggio 2006; Goleman 1998; Goleman 2001a; Janasz et al. 2006; Robbins et al. 2012; Robbins and Hunsaker 2009; Strohmeier 1992), but there is a lack of research that investigates their roles and functions in the context of construction safety.

As such, the aims of this research are twofold: the first is to investigate the influence of emotional intelligence, interpersonal skill, and transformational leadership on construction safety in terms of implementing safety management tasks and developing safety climate; and the second is to reveal the interrelationship between emotional intelligence, interpersonal skill, and transformational leadership, which may serve as a guideline for project management personnel to develop their human skills.

\section{Literature Review}

\section{Emotional Intelligence}

Emotional intelligence is "the capacity for recognising our own feelings and those of others, for motivating ourselves, and for managing emotions well in ourselves and in our relationships" (Goleman 1998, p. 375). Emotional intelligence is increasingly being recognised as an important quality at work. Studies have found that high IQ alone does not guarantee a successful life and there are cases where individuals with higher IQ work for people with lower IQ (Goleman 1995, 1998). Although certainly there is a minimum baseline IQ as being necessary for effective performance, emotional intelligence may be twice as important as IQ in contributing to excellent and effective performance (Dulewicz and Higgs 2000; Goleman 1998). Further studies have shown that $\mathrm{IQ}$ is a more powerful predictor than emotional intelligence in determining which fields or professions people should enter, but when studies look within a job or profession, emotional intelligence is a more powerful predictor of success than IQ (Goleman 2001b).

In general, emotional intelligence can be classified into four dimensions: self-awareness, selfmanagement, social awareness, and relationship management (Bradberry and Greaves 20012010; Goleman 2001a). First, self-awareness is to know one's own feeling as it happens and

Sunindijo, R Y and Zou, P X W (2013) 'The roles of emotional intelligence, interpersonal skill, and transformational leadership on improving construction safety performance', Australasian Journal of Construction Economics and Building, 13 (3) 97-113 
use it in decision making. Individuals high in self-awareness are aware of their strengths and weaknesses, open to feedback, and willing to learn from past experiences. Second, selfmanagement is the ability to regulate distressing effects, such as anxiety and anger, and to restrain emotional impulsivity. Using self-management, individuals are able to hold in mind the positive feelings that will come when they achieve goals and inhibit the negative feelings. Additionally, individuals high in self-management are often able to boost motivation. Third, social awareness enables individuals to recognise other people's feelings. Individuals with high social awareness have an ability to read nonverbal cues for emotional currents from others. This skill is particularly critical for job performance when the focus is on interactions with people. Lastly, relationship management is the ability to attune oneself to and influence the emotions of others (Goleman 2001a). Relationship management enables a person to use the awareness of one's own emotions and the emotions of others to successfully manage interactions (Bradberry and Greaves 2001-2010).

\section{Interpersonal Skill}

Interpersonal skill is the ease and comfort of communication between individuals and their colleagues, superiors, subordinates, clients, and other stakeholders (Peled 2000). Interpersonal skill includes the ability to motivate others, conflict management, effective communication, and team building (Sunindijo and Zou, 2011; Strohmeier 1992). Motivation is the arousal, direction, and persistence of behaviour (Steers and Porter 1991). In order to motivate others, project management personnel have to determine what drives people to exhibit certain behaviour, what directs or channels people's behaviour, and how the behaviour is sustained (Steers and Porter 1991; Lingard and Rowlinson 2005).

Project management personnel should be flexible, depending on the situation, in using different styles to manage conflicts. There are five conflict resolution styles based on the levels of assertiveness and cooperativeness: avoiding, dominating, accommodating, compromising, and collaborating (Samson and Daft 2009). Furthermore, in order to manage social interactions, project management personnel should also be effective communicators to ensure that all stakeholders are 'on the same page' throughout construction life cycle. They have to listen effectively; have strong verbal, graphical, and written communication skills; deliver good and bad news effectively; have strong presentation skills; and be able to liaise among stakeholders (Brill et al. 2006).

Lastly, project management personnel should be able to build teamwork and cooperation by showing genuine intention to work cooperatively with others and use different approaches to get the best out of the team (Cheng et al. 2005). A construction project team is temporary where people, in many cases from different organisations, come together for only one project with no guarantee of ever doing so again (Cornick and Mather 1999; Ong 2008). This type of team has distinct characteristics and offers more challenges than the teams in other industries. Teambuilding and teamwork, therefore, is crucial for managing the knowledge and skills of the human capital and making them as a competitive advantage instead of an inhibitor of delivering successful projects (Verma 1995).

\section{Transformational Leadership}

Leadership theories have evolved considerably from the trait theory to the behavioural theory and to the contingency theory. A contemporary view of leadership has proposed the concept of transformational leadership, which is able to stimulate and inspire followers to go beyond their own self-interest to achieve extraordinary outcomes for the good of the organisation. Transformational leaders pay attention to the concerns and developmental needs of individual

Sunindijo, R Y and Zou, P X W (2013) 'The roles of emotional intelligence, interpersonal skill, and transformational leadership on improving construction safety performance', Australasian Journal of Construction Economics and Building, 13 (3) $97-113$ 
followers. They also help the followers to look at old problems in new ways and are able to inspire them to give extra effort to achieve common goals (Robbins et al. 2012). Prabhakar (2005) found that project managers who are strong transformational role models and use a relationship-oriented approach towards their project team enjoy greater success than their counterparts. Another research found that a transformational CEO motivates and inspires others to excel towards both organisational and individual excellence (Zhu et al. 2005). In the healthcare industry, safety-specific transformational leadership training is considered as a low cost intervention that has positive effects on a variety of safety outcomes including safety climate (Mullen and Kelloway 2009).

There are four characteristics of transformational leaders. First, idealised influence by behaving in ways that allow them to serve as role models for their followers, thus making the leaders admired, respected, and trusted. Transformational leaders are endowed by their followers as having extraordinary capabilities, persistence, and determination. Second, inspirational motivation works by providing meaning and challenge to their followers' work. Transformational leaders clearly communicate expectations and demonstrate commitment to goals and the shared vision. These first two characteristics are similar to the behaviours of charismatic leaders. Third, intellectual stimulation or stimulating inspires followers to be innovative and creative by questioning assumptions, reframing problems, and approaching old situations in new ways. Fourth, individualised consideration operates by giving special attention to each individual follower's needs for achievement and growth by acting as a coach or mentor (Bass and Riggio 2006).

\section{Safety Performance Indicator in Construction Projects}

Three common methods used to assess safety performance in the construction industry are accident rate $(A R)$, incidence rate $(I R)$, and experience modification rating (EMR). AR and IR assess safety performance based on the numbers or rates of accident and incident. They are unreliable because their accuracy depends on the honesty of organisations in reporting their accidents and incidents. The EMR, on the other hand, reflects the cost that organisations have to pay for workers' compensation insurance. It is the ratio between actual claims filed and expected claims for a particular type of construction. The problem with EMR is that its formulae are quite complex and there are different versions of calculation. Furthermore, EMR is based on the running average results over several years, which cannot reflect the latest safety performance of an organisation ( $\mathrm{Ng}$ et al. 2005).

Due to the limitations of these measurement instruments and tools, safety climate has become an alternative to assess safety performance. Safety climate is "shared employee perceptions of how safety management is being operationalised in the workplace, at a particular moment in time" (Cooper and Phillips 2004, p. 497). Safety climate has been used to predict safety performance for more than two decades, although, as compared to the other industries, safety climate is relatively new in the construction industry. Nevertheless, research studies have shown that safety climate is a good indicator to assess safety performance in the construction industry (Mohamed 2002). Studies have also revealed the reliability of safety climate in measuring safety-related outcomes, such as the number of accidents and injuries (Glendon and Litherland 2001). Mohamed (2002) found positive association between safety climate and safe work behaviour. Another research finding shows that safety climate is correlated with the safety level of work environment, better safety practices, and lower accident rate (Varonen and Mattila 2000). Furthermore, safety climate is viewed as a predictor of injury severity and frequency (Johnson 2007) as well as related to self-report of compliance with safety procedures and participation in safety-related activities within the workplace (Neal et al. 2000).

Sunindijo, R Y and Zou, P X W (2013) 'The roles of emotional intelligence, interpersonal skill, and transformational leadership on improving construction safety performance', Australasian Journal of Construction Economics and Building, 13 (3) $97-113$ 


\section{Research Hypotheses}

The three human skill components, i.e., emotional intelligence, interpersonal skill, and transformational leadership, are seen as useful in managing construction safety. Emotional intelligence helps project management personnel distinguish the emotional currents of others and enables them to apply the 'right' approaches when encouraging others to follow safety standards. Furthermore, emotional intelligence and interpersonal skill work together to promote teamwork and cooperation, and motivate people to remain focused on safety. In addition, emotional intelligence and interpersonal skill also help project management personnel resolve conflicts that may hinder the attainment of safety goals. Interpersonal skill is also important to establish effective communication during safety implementation. Transformational leadership is needed by project management personnel to become safety leaders who set themselves as positive examples and inspire others to uphold safety.

Dingsdag et al. (2006) have identified 39 safety management tasks that project management personnel should perform for this purpose. A safety management task is described as a definable activity, action or process that project management personnel should perform to provide safety leadership. With a strong leadership, project management personnel will be able to promote safety vision, guide all project stakeholders to perform their work safely, and encourage them to contribute to creating a safe work environment. This leads to the development of safety climate, which is the safety indicator in this present research, and eventually promotes the overall improvement of safety performance.

A theoretical model proposed for this research, as shown in Figure 1, shows the potential relationships between the independent variables and dependent variables. In the theoretical model, emotional intelligence is an initiator, signifying that project management personnel should start inwardly by understanding and managing emotions (both self and others). This emotional intelligence is then manifested in the form of effective social interactions through the application of interpersonal skill. Thereafter, these effective interactions allow project management personnel to become transformational leaders who generate superior performance from their teams. These three human skill components positively influence implementation of safety management tasks, which leads to development of safety climate. Based on this theoretical model, six hypotheses were formulated for this research, as follow:

- Hypothesis 1: The higher the emotional intelligence, the higher the interpersonal skill.

- Hypothesis 2: The higher the interpersonal skill, the higher the transformational leadership.

- Hypothesis 3: Emotional intelligence has positive influence on the implementation of safety management tasks.

- Hypothesis 4: Interpersonal skill positively affects the implementation of safety management tasks.

- Hypothesis 5: The higher the transformational leadership, the higher the implementation of safety management tasks.

- Hypothesis 6: Implementation of safety management tasks influences the development of construction safety climate. 


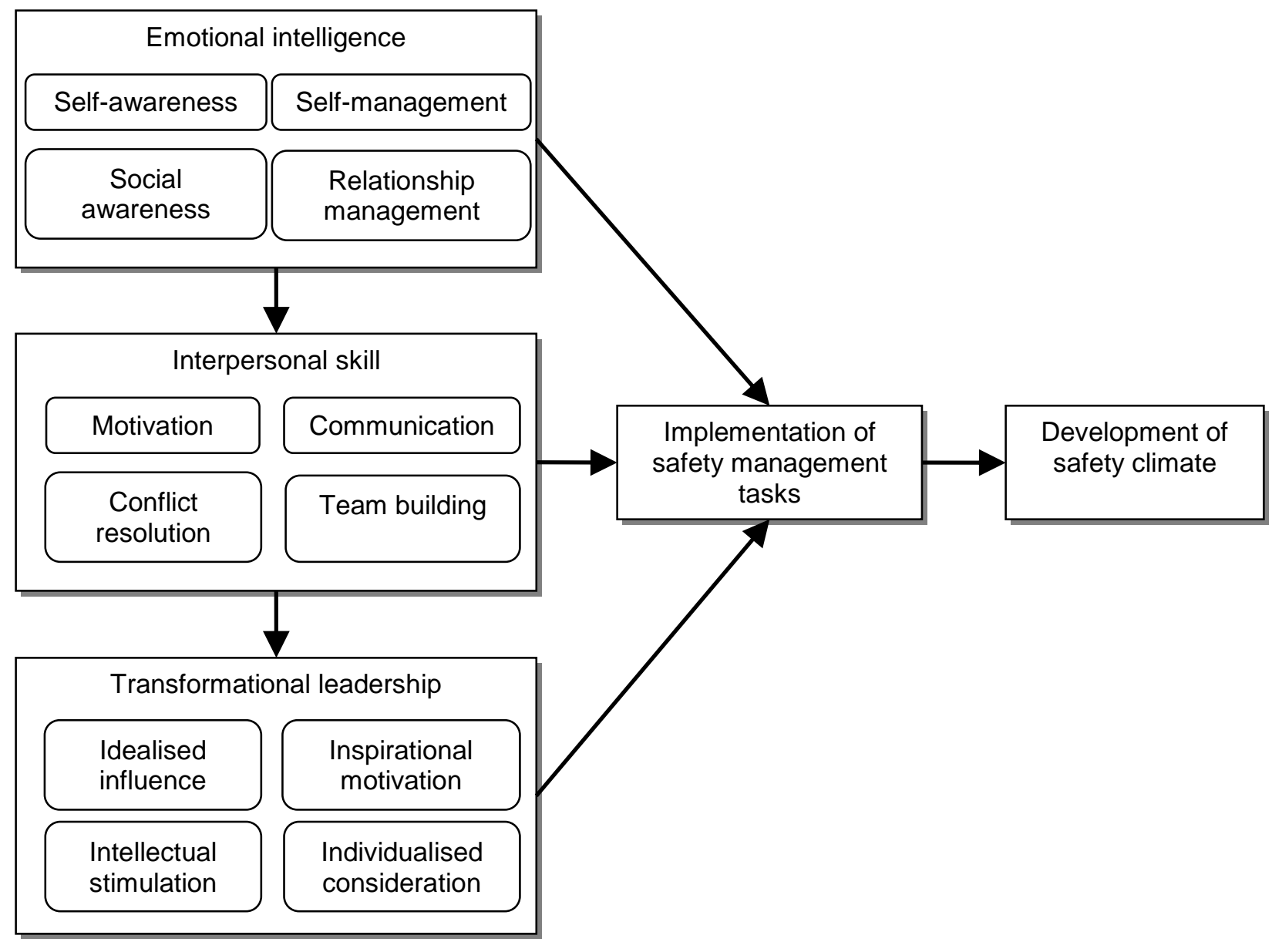

Figure 1 The theoretical model for this research

\section{Research Methods}

\section{Questionnaire Design and Development}

The aim of this research is theory testing which involves determining the degree of relationships among independent and dependent variables. Since a large sample of quantitative data was required to test the theoretical model, a questionnaire survey was the most appropriate data collection method. The questionnaire for this research consists of five sections as summarised in Table 1. The majority of the items were drawn from questionnaires used in previous studies and the Likert scale range from five to seven points. For analysis purpose, the result from each section of the questionnaire was interpolated into a five-point scale.

\begin{tabular}{|l|c|l|}
\hline \multicolumn{1}{|c|}{ Section } & No of items & \multicolumn{1}{c|}{ Source } \\
\hline Emotional Intelligence Appraisal & 28 & Bradberry and Greaves (2001-2010) \\
\hline Interpersonal skill & 12 & Literature review \\
\hline Global Transformational Leadership & 7 & Carless et al. (2000) \\
\hline Safety management tasks & 39 & Dingsdag et al. (2006) \\
\hline Safety climate & 20 & Sunindijo and Zou (2012) \\
\hline
\end{tabular}

Table 1 List of questionnaires used in this research

Sunindijo, R Y and Zou, P X W (2013) 'The roles of emotional intelligence, interpersonal skill, and transformational leadership on improving construction safety performance', Australasian Journal of Construction Economics and Building, 13 (3) $97-113$ 
The first section is the 28-item Emotional Intelligence Appraisal which was designed to assess the four dimensions of emotional intelligence. It uses a six-point Likert scale format ranging from 'never' to 'always'. The questionnaire has been validated across industries and job positions (Bradberry and Greaves 2001-2010).

The second section assesses the interpersonal skill of project management personnel, and it contains 15 items, which were derived from a comprehensive review of the literature (such as Carlopio and Andrewartha 2008; Culp and Smith 1992; Robbins et al. 2012; Strohmeier 1992). A five-point Likert scale format ranging from 'strongly disagree' to 'strongly agree' was used in this section. After psychometric tests (discussed in the next section), 12 items were retained and used for analysis. The 12 items for assessing interpersonal skill are attached in Appendix A.

The third section is the Global Transformational Leadership (GTL) scale, which contains seven items (Carless et al. 2000). A five-point Likert scale format ranging from 'rarely or never' to 'frequently or always' was used in this section. The GTL has been tested in Australia with satisfactory reliability and validity to measure transformational leadership.

The fourth section assesses the level of implementation of safety management tasks. This section uses a five-point Likert scale format ranging from 'poor' to 'good'. It was developed based on the 39 safety management tasks identified by Dingsdag et al. (2006) with significant input and satisfactory validation from the Australian construction industry.

The fifth section is for assessing safety climate and was developed based on the review of previous safety climate studies. Initially, 157 safety climate items were identified. Following the results of item analysis and factor analysis, a 20-item safety climate questionnaire was finalised. A five-point Likert scale format is used in this section, ranging from 'strongly disagree' to 'strongly agree'. Readers interested in the refinement process of the safety climate items may refer to Sunindijo and Zou (2012).

\section{Data Collection}

Data were collected using a web-based questionnaire survey from three large construction organisations in Australia. Prior to the distribution of the questionnaire, a pilot study was conducted including 10 academics and industry practitioners. The questionnaire items, particularly those related to the interpersonal skill and safety climate were revised according to their feedback. This revision mainly involved wording modifications to avoid ambiguity and further clarification in the cover letter concerning the objectives of the study. Thereafter, the authors met with safety managers of the participating organisations to explain the aims and benefits of the research. Project management personnel who were working in construction projects at the time of the survey were invited to participate in the survey.

In total, 356 respondents participated of which 273 responses were valid and useful for further analysis. Various project management personnel have participated, ranging from safety personnel $(\mathrm{N}=27,9.9 \%)$, site supervisors $(\mathrm{N}=23,8.4 \%)$, engineers $(\mathrm{N}=58,21.2 \%)$, site managers $(\mathrm{N}=28,10.3 \%)$, project managers $(\mathrm{N}=53,19.4 \%)$, and construction managers $(\mathrm{N}=26$, $9.5 \%)$. Other job positions $(\mathrm{N}=58,21.2 \%)$ include risk managers, sustainability and environmental personnel, design and planning personnel, commissioning managers, and cost planners. On average, the respondents have worked in the construction industry for more than 18 years.

Sunindijo, R Y and Zou, P X W (2013) 'The roles of emotional intelligence, interpersonal skill, and transformational leadership on improving construction safety performance', Australasian Journal of Construction Economics and Building, 13 (3) $97-113$ 


\section{Data Analysis Methods}

Structural equation modelling (SEM) was the main method applied to test the hypotheses of this research. SEM is suitable for this research because it provides a quantitative test of a theoretical model so that complex relationships among variables can be understood (Schumacker and Lomax 2010). Many of the research topics in construction management involve the measurement of constructs that are not easily quantified, e.g., human skills and safety climate. Although standardised multivariate regression methods had been adopted successfully in past research, there is a fundamental issue with their use. A basic premise of standard regression methods is that independent variables used to build the regression models are measured without error, which is often not the case. For example, emotional intelligence is not measured directly, but through proxy variables that make up scope definition. These variables typically do not perfectly measure the prime variable of interest, thus causing technical problems in model estimation and diminishing ability to conduct statistical inferences. In this case, SEM is an extension of standardised regression modelling that deals with these poorly measured independent variables (Molenaar et al. 2000).

\section{Results and Discussions}

All survey questionnaire items, except the items related to interpersonal skill, have undergone psychometric tests as explained in the previous section, thus the process is not repeated in this paper. Factor analysis with principal components method and varimax rotation was used to validate the initial 15 interpersonal skill items. When the sample size is more than 250 , it was suggested to use 0.35 as a cut-off requirement (Cranfield University 1998). All factor loadings were more than 0.35 , thus indicating that all items should be retained. The next step was to determine the factor structure of the questionnaire using factor analysis with principal axis method and varimax rotation. After three iterations, three items were eliminated because their factor loadings were less than 0.35 . The remaining 12 items have a Cronbach's alpha value of 0.825 , indicating that the questionnaire is reliable.

The result of the SEM analysis is presented in Figure 2, while the un-standardised and standardised regression weights are given in Table 2. Maximum likelihood estimation was adopted in the analysis process. Table 3 presents the means, standard deviations, and correlation matrix of the research variables. The fit indices of the theoretical model (Figure 1) did not fit the data well. As such, it was modified which resulted in the best-fit model depicted in Figure 2. All the relationships in the best fit model are supported by the existing literature as explained in the next sections.

The chi-square value is 17.712 with 13 degrees of freedom. The probability value of the chisquare test is higher than $0.05(p=0.169)$ indicating that the model fits the data. Other fit indices also indicate good fit. The root mean square error of approximation (RMSEA) is 0.037 where values less than 0.05 indicate good fit (Byrne, 2010). The value of the standardised root mean square residual (SRMR) at 0.031 also meet the acceptable threshold level of less than 0.08 . The comparative fit index (CFI) is 0.995 in which values of greater than 0.95 are recognised as good fit. Lastly, the non-normed fit index (NNFI) is 0.990 and being greater than 0.95 indicates a good fit (Hooper et al., 2008). The numbers on the arrows are the un-standardised regression weights (ranging from 0 to 1). An un-standardised regression coefficient represents the amount of change in dependent variable per single unit change in the predictor variable. For example, for every single unit of increase in self-awareness, the level of self-management is increased by 0.49. All coefficients are statistically significant, providing strong support for the hypothesised model.

Sunindijo, R Y and Zou, P X W (2013) 'The roles of emotional intelligence, interpersonal skill, and transformational leadership on improving construction safety performance', Australasian Journal of Construction Economics and Building, 13 (3) $97-113$ 
It is clear that the research results support Hypotheses 1 and 2. The best-fit model confirms the theoretical relationships proposed in this research where emotional intelligence is a prerequisite of effective interpersonal relationship, which in turn influences transformational leadership effectiveness. Furthermore, emotional intelligence (represented by self-management and relationship management dimensions) is a predictor of the implementation of safety management tasks, a result that supports Hypothesis 3. However, Hypotheses 4 and 5 are not supported by the model shown in Figure 2. Instead, it shows that transformational leadership can be applied directly to develop safety climate, while interpersonal skill is a key competence of transformational leaders, but does not have any direct role in construction safety. Lastly, the model supports Hypothesis 6 indicating that the implementation of safety management tasks leads to the development of safety climate.

\begin{tabular}{|l|c|c|c|c|c|c|c|c|c|c|}
\hline & Mean & SD & $\mathbf{1}$ & $\mathbf{2}$ & $\mathbf{3}$ & $\mathbf{4}$ & $\mathbf{5}$ & $\mathbf{6}$ & $\mathbf{7}$ & $\mathbf{8}$ \\
\hline 1. Self-awareness & 3.82 & .57 & 1 & & & & & & & \\
\hline 2. Self-management & 3.92 & .49 & .557 & 1 & & & & & & \\
\hline 3. Social awareness & 3.74 & .51 & .554 & .561 & 1 & & & & & \\
\hline $\begin{array}{l}\text { 4. Relationship } \\
\text { management }\end{array}$ & 3.81 & .53 & .576 & .622 & .675 & 1 & & & & \\
\hline 5. Interpersonal skill & 3.85 & .41 & .482 & .530 & .542 & .655 & 1 & & & \\
\hline $\begin{array}{l}\text { 6. Transformational } \\
\text { leadership }\end{array}$ & 4.31 & .51 & .470 & .520 & .500 & .590 & .650 & 1 & & \\
\hline $\begin{array}{l}\text { 7. Safety management } \\
\text { tasks }\end{array}$ & 3.90 & .66 & .272 & .378 & .303 & .426 & .339 & .329 & 1 & \\
\hline \begin{tabular}{l} 
8. Safety climate \\
\hline
\end{tabular} & 4.12 & .53 & .244 & .304 & .302 & .351 & .298 & .349 & .682 & 1 \\
\hline
\end{tabular}

Table 3 Means, standard deviations, and correlation matrix of research variables

\section{Interrelationships among the Dimensions of Emotional Intelligence}

Based on the best-fit model (Figure 2), self-awareness is the prerequisite of the other three dimensions and also initiates all the relationships. Self-awareness is an ability that has been appreciated since ancient times. Recent research has also found that individuals with high selfawareness understand their strengths and limitations, a competency prominent among best performing managers. Individuals high in self-awareness seek feedback, learn from their mistakes, and understand when to work with others who have complementary strengths (Goleman 2001a). This understanding of oneself brings about greater understanding of others, making these individuals appear trustworthy and competent (Janasz et al. 2006). Furthermore, self-awareness provides necessary information that forms the basis of self-reinforcement or goal establishment, which is a prerequisite of self-management (Manz and Sims Jr. 1980). All these result in the development of self-confidence, which is a significant predictor of performance (Goleman 2001a). In short, the finding of this research supports a proposition stating that self-awareness is a core and starting point of emotional intelligence (Jordan and Ashkanasy 2006) as well as a key to succeed and work effectively with others (Janasz et al. 2006).

Next, self-management is a predictor of social awareness and relationship management. The relationships are evident given that individuals who cannot control their emotional outbursts will

Sunindijo, R Y and Zou, P X W (2013) 'The roles of emotional intelligence, interpersonal skill, and transformational leadership on improving construction safety performance', Australasian Journal of Construction Economics and Building, 13 (3) $97-113$ 
have less chance to be effective in understanding others and developing relationships (Goleman 2001a). At a neurological level, it was found that self-management is a foundation of social effectiveness (Damasio 1994). A study involving children with autism found that selfmanagement can be used to improve social skills (Koegel et al. 1992).

The SEM results also show that social awareness is a predictor of relationship management. Understanding of one's own emotions and the emotions of others is a way to create effective social interactions (Lane 2000). Individuals with high social awareness understand different points of view, making them effective in their interactions with different types of people. It is easier for them to get along in organisational life, build networks, and employ influence tactics to achieve positive results (Robbins and Hunsaker 2009). This interrelationship among the dimensions of emotional intelligence corroborates a research study which found that relationship management depends on a foundation of self-management and social awareness, each of which in turn requires self-awareness (Goleman 2001a).

\section{Emotional Intelligence and Interpersonal Skill}

The SEM results show that emotional intelligence, particularly the self-management, social awareness, and relationship management dimensions, is a prerequisite of effective application of interpersonal skill. It is a fact that individuals have to be effective self-managers before overcoming barriers to interpersonal effectiveness because self-management gives individuals credibility in their interactions with others. This credibility along with the capacity to manage emotional outbursts are keys to effective communication, which is a foundation to resolve conflicts and build teamwork (Janasz et al. 2006). Furthermore, self-management is a source of achievement drive (an optimistic striving to improve performance) and initiative (being proactive in seizing opportunities and pursuing goals beyond what is required), which are crucial for motivating oneself and others (Goleman 1998). Sunindijo et al. (2007) found that social awareness is related to sharing and open communication. This sensitivity to others is critical for superior job performance whenever the focus is on interactions with people. Furthermore, socially aware individuals are emphatic. They have an ability to put themselves in someone else's shoes, sense their emotions, and understand their perspective, thus enabling them to interact effectively with different types of personalities (Robbins and Hunsaker 2009). This explains why social awareness is a prerequisite of interpersonal skill.

Among the three dimensions, relationship management has the highest opportunity to influence the application of interpersonal skill (coefficient 0.33 vs. 0.16 and 0.12). Goleman (2001a) suggested that the relationship management dimension is useful to develop, coach, mentor, and persuade others to achieve common goals. It generates effective communication and conflict management. It is also required in the processes of networking, collaboration, and teamwork. Individuals skilled in relationship management use their understanding of emotions to inspire change and lead others towards better performance (Robbins and Hunsaker 2009). In essence, this dimension is essential to manage interpersonal issues that may happen in the construction project environment.

\section{Emotional Intelligence, Interpersonal Skill, and Transformational Leadership}

The best-fit model shows that relationship management and interpersonal skill are predictors of transformational leadership. Goleman (2001a) suggested that individuals competent in relationship management are able to sense the developmental needs of others, making them excellent coaches and mentors. They are influential and can articulate a shared vision that arouses enthusiasm and inspires others to work together towards common goals. They are also change catalysts which bring greater efforts and better performance from their subordinates. In

Sunindijo, R Y and Zou, P X W (2013) 'The roles of emotional intelligence, interpersonal skill, and transformational leadership on improving construction safety performance', Australasian Journal of Construction Economics and Building, 13 (3) $97-113$ 
short, relationship management generates competencies required by individuals to be transformational leaders.

In this research, it is found that interpersonal skill is the dominant factor that influences the effectiveness of transformational leadership (coefficient 0.64). This finding supports a proposition suggested by Elmuti et al. (2005) who argued that interpersonal skill, such as communication, teamwork, and conflict management, has to be incorporated into an existing leadership education model to develop future transformational leaders. Doh (2003) also considered interpersonal skill as one of the essential factors that determines transformational leadership success. In practice, transformational leaders have to exercise their interpersonal skill to interact effectively with others. There is no leadership without these interactions. Therefore, individuals need to apply interpersonal skill to communicate, motivate, resolve conflicts, and build teamwork before they can be effective leaders.

\section{Emotional Intelligence and Safety Management Tasks}

The model further shows that two dimensions of emotional intelligence, i.e., self-management and relationship management, are required to perform safety management tasks. Selfmanagement can be considered as the process of planning, organising, directing, and controlling oneself. It is a form of self-leadership where individuals need to motivate themselves to achieve their goals (Robbins and Hunsaker 2009). In practising self-management, project management personnel should include safety as one of their values and goals. This, in effect, will influence their decisions and behaviour, motivating them to implement safety management tasks. Achievement drive and initiative are two competencies of individuals with high selfmanagement (Goleman 2001a). Achievement drive is an optimistic determination to continually improve performance, which can become a key ingredient for project management personnel to perform safety management tasks amid setbacks or difficulties. Initiative, on the other hand, makes project management personnel proactive in tackling safety problems. They understand the importance of performing safety management tasks, thus they are willing to implement those tasks before being forced by external events to do so (Goleman 2001a).

Relationship management is also critical (with a coefficient of 0.39) in implementation of safety management tasks, particularly in construction project environment where project stakeholders are numerous and diverse. Safety management tasks require project management personnel to interact with project stakeholders and the workforce. Consequently, relationship management is needed to relate with others in ways that nurture positive relationships (Robbins and Hunsaker 2009), thus enabling project management personnel to make the most out of every interaction (Bradberry and Greaves 2009) when implementing those tasks.

\section{Transformational Leadership, Safety Management Task Implementation and Safety Climate Development \\ The SEM results show that implementation of safety management tasks (coefficient 0.49 ) and transformational leadership (coefficient 0.16 ) are the predictors of construction safety climate development. Safety task implementation is a key factor that promotes safety climate development as anticipated in Hypothesis 6. When project management personnel perform the required safety management tasks, they provide safety leadership in their projects, thus positively influencing the attitudes and perceptions of others towards safety. These attitudes and perceptions shape safety climate in construction projects. This confirms the findings claimed by Dingsdag et al. (2006) indicating that the capability of undertaking safety management tasks develops positive safety attitudes and improves safety performance.}

Sunindijo, R Y and Zou, P X W (2013) 'The roles of emotional intelligence, interpersonal skill, and transformational leadership on improving construction safety performance', Australasian Journal of Construction Economics and Building, 13 (3) $97-113$ 
Transformational leadership can contribute to safety climate development because it builds safety commitment. Project management personnel should become role models in order to build this safety commitment. They need to inspire others by articulating a clear vision and showing the moral values of safety, thus increasing the intrinsic value of achieving safety goals. Such a charismatic approach should be supported by necessary training and mentoring to provide others with a sense of increased competence to carry out safety management responsibilities. This creates more satisfied followers, while simultaneously promotes positive perceptions and attitudes towards safety which basically refer to safety climate (Bass and Riggio 2006).

\section{Limitations of the Research and Future Research}

There are several limitations in this research need mentioning. First, the data were selfassessed, thus a common-method bias may have occurred. For instance, different respondents may have different interpretations concerning what is the standard of good safety climate or high level of safety management task implementation. In spite of this limitation, this research offers empirical evidence and support for the theoretical research model showing the relationships between the research variables. Second, the data were collected from large construction organisations in Australia. Although care has been taken in selecting the research samples, these organisations may not represent the whole construction industry at the national level, thus the results are tentative and must be cautiously interpreted and applied. Future research may collect data from medium- and small-sized construction organisations to compare the results. Nevertheless, these limitations should not nullify the theory augmentation and practical contributions derived from the empirical evidence found in this research. Third, there are other human factors, such as human resource development program, political skill, resilience intelligence, and organisational/project culture, which may have impacts on construction safety besides the three included in this paper. Future research should investigate their impacts on construction safety and their relationships with the three human skill components discussed here. A comprehensive model could be developed to map the relationships between different constructs. Fourth, the validity of the proposed model may be tested more rigorously. As such, there is a need for future studies to employ larger samples, thus enabling them to be split into estimation and validation samples.

\section{Conclusion}

The findings of this research has provided empirical evidence showing that project management personnel can use human skills, which consist of emotional intelligence, interpersonal skill, and transformational leadership, to improve safety in construction projects. It is found that emotional intelligence is a prerequisite of effective implementation of safety management tasks. Furthermore, transformational leadership and implementation of safety management tasks, in conjunction with indirect influence from interpersonal skill, promote the development of safety climate, which is an important leading indicator of construction safety performance.

In order to improve their human skills, project management personnel should start from their emotional intelligence, particularly their self-awareness. Self-awareness is a core factor that contributes to the improvement of individual performance and development of effective relationships with others. Following this, they should develop their self-management and social awareness, which are important to control one's own emotions and understand the emotions of others. Thereafter, they should learn to manifest their emotional intelligence, i.e., relationship management, by exercising their interpersonal skill to communicate effectively, motivate others, resolve conflicts, and build teamwork. These social interactions are required for project management personnel to be transformational leaders who inspire their teams to generate

Sunindijo, R Y and Zou, P X W (2013) 'The roles of emotional intelligence, interpersonal skill, and transformational leadership on improving construction safety performance', Australasian Journal of Construction Economics and Building, 13 (3) $97-113$ 
superior performance in construction project safety. This development process leads to effective safety task implementation which promotes safety climate development.

Practically, construction organisations should recognise the role of human skills in construction safety management and provide relevant training and development strategies for their project management personnel. Furthermore, construction organisations should consider integrating the assessment of emotional intelligence, interpersonal skill and transformational leadership in their human resource recruitment and development programs to identify, develop, and employ individuals who can make significant contribution to safety performance improvement and organisational success as a whole.

\section{Acknowledgements}

The authors would like to thank the participating companies, senior managers, safety managers, and respondents who contributed to or participated in this research. The authors are also grateful to TalentSmart that provided the Emotional Intelligence Appraisal at a discounted price.

\section{References}

ACT Government 2012, Getting Home Safely: Inquiry into Compliance with Work Health and Safety Requirements in the ACT's Construction Industry, ACT Government, Canberra.

Bass, B.M. \& Riggio, R.E. 2006, Transformational Leadership, 2nd ed., Lawrence Erlbaum Associates, Mahwah, NJ.

Bradberry, T. \& Greaves, J. 2001-2010, The Emotional Intelligence Appraisal - Me Edition: There is more than IQ. TalentSmart, San Diego.

Bradberry, T. \& Greaves, J. 2009, Emotional Intelligence 2.0, TalentSmart, San Diego.

Brill, J.M., Bishop, M.J., \& Walker, A.E. 2006, 'The competencies and characteristics required of an effective project manager: A web-based Delphi study', Educational Technology Research and Development, 54 (2), 115-140.

Byrne, B.M. 2010, Structural Equation Modeling with AMOS: Basic Concepts, Applications, and Programming, 2nd ed., Routledge, New York.

Carless, S.A., Wearing, A.J., \& Mann, L. 2000, 'A short measure of transformational leadership', Journal of Business and Psychology, 14 (3), 389-405.

Carlopio, J. \& Andrewartha, G. 2008, Developing Management Skills: A Comprehensive Guide for Leaders, 4th ed., Pearson Education Australia, Frenchs Forest, NSW.

Cheng, M., Dainty, A.R.J., \& Moore, D.R. 2005, 'What makes a good project manager?', Human Resource Management Journal, 15 (1), 25-37.

Cooper, M.D. \& Phillips, R.A. 2004, 'Exploratory analysis of the safety climate and safety behavior relationship', Journal of Safety Research, 35 (5), 497-512.

Cornick, T. \& Mather, J. 1999, Construction Project Teams: Making Them Work Profitably, Thomas Telford Publishing, London.

Cranfield University 1998, Factor Analysis, Retrieved from http://www.networkedcranfield.com/cell/Pages/MSc\%20Knowledgebase.aspx?RootFolder=\%2fc ell\%2fKnowledgebase\%2fQuants\%20Material\&FolderCTID=\&View $=\{28 F 86061-D 0 C 7-4 E 2 E-$ B908-A256E51D6191 (Accessed January 2012).

Culp, G. \& Smith, A. 1992, Managing People (Including Yourself) for Project Success, John Wiley and Sons, New York.

Sunindijo, R Y and Zou, P X W (2013) 'The roles of emotional intelligence, interpersonal skill, and transformational leadership on improving construction safety performance', Australasian Journal of Construction Economics and Building, 13 (3) $97-113$ 
Damasio, A. 1994, Descartes' Error: Emotion, Reason, and the Human Brain, Grosset/Putnam, New York.

Dingsdag, D.P., Biggs, H.C., Sheahan, V.L., \& Cipolla, D.J. 2006, A Construction Safety Competency Framework: Improving OH\&S Performance by Creating and Maintaining a Safety Culture, Cooperative Research Centre for Construction Innovation, Icon.Net.

Doh, J.P. 2003, 'Can leadership by taught? Perspectives from management educators', Academy of Management Learning \& Education, 2 (1), 54-67.

Dulewicz, V. \& Higgs, M. 2000, 'Emotional intelligence - a review and evaluation study', Journal of Managerial Psychology, 15 (4), 341-372.

Elmuti, D., Minnis, W., \& Abebe, M. 2005, 'Does education have a role in developing leadership skills?', Management Decision, 43 (7), 1018-1031.

Glendon, A.I. \& Litherland, D.K. 2001, 'Safety climate factors, group differences and safety behaviour in road construction', Safety Science, 39 (3), 157-188.

Goleman, D. 1995, Emotional Intelligence: Why It Can Matter More Than IQ, Bantam Books, New York.

Goleman, D. 1998, Working with Emotional Intelligence, Bloomsbury, London.

Goleman, D. 2001a, 'An El-based theory of performance'. In Cherniss, C. \& Goleman, D. (eds.), The Emotionally Intelligent Workplace, Jossey-Bass, San Francisco, 27-44.

Goleman, D. 2001b., 'Emotional intelligence: issues in paradigm building'. In Cherniss, C. \& Goleman, D. (eds.), The Emotionally Intelligent Workplace, Jossey-Bass, San Francisco, 13-26.

Hooper, D., Coughlan, J., \& Mullen, M.R. 2008, 'Structural equation modelling: guidelines for determining model fit', The Electronic Journal of Business Research Methods, 6 (1), 53-60.

Janasz, S.D., Wood, G., Gottschalk, L., Dowd, K., \& Schneider, B. 2006, Interpersonal Skills in Organisations, McGraw-Hill, Boston.

Johnson, S. 2007, 'The predictive validity of safety climate', Journal of Safety Research, 38 (5), 511-521.

Jordan, P.J. \& Ashkanasy, N.M. 2006, 'Emotional intelligence, emotional self-awareness, and team effectiveness'. In: Druskat, V.U., Sala, F., \& Mount, G. (Eds.), Linking Emotional Intelligence and Performance at Work: Current Research Evidence with Individuals and Groups, Lawrence Erlbaum Associates, New Jersey, 145-163.

Koegel, L.K., Koegel, R.L., Hurley, C., \& Frea, W.D. 1992, 'Improving social skills and disruptive behavior in children with autism through self-management', Journal of Applied Behavior Analysis, 25 (2), 341-353.

Lane, R.D. 2000, 'Levels of emotional awareness: neurological, psychological, and social perspectives'. In: Bar-On, R. Parker, J.D.A. (Eds.), The Handbook of Emotional Intelligence, Jossey-Bass, San Francisco, 171-191.

Langford, D., Rowlinson, S., \& Sawacha, E. 2000, 'Safety behaviour and safety management: its influence on the attitudes of workers in the UK construction industry', Engineering, Construction and Architectural Management, 7 (2), 133-140.

Lingard, H. \& Rowlinson, S. 2005, Occupational Health and Safety in Construction Project Management, Spon Press, Oxon.

López, M.A.C., Ritzei, D.O., Fontaneda, I., \& Alcantara, O.J.G. 2008, 'Construction industry accidents in Spain', Journal of Safety Research, 39 (5), 497-507.

Sunindijo, R Y and Zou, P X W (2013) 'The roles of emotional intelligence, interpersonal skill, and transformational leadership on improving construction safety performance', Australasian Journal of Construction Economics and Building, 13 (3) $97-113$ 
Manz, C.C. \& Sims Jr., H.P. 1980, 'Self-management as a substitute for leadership: A social learning theory perspective', Academy of Management Review, 5 (3), 361-367.

McGeorge, D. \& Zou, P.X.W. 2013, Construction Management: New Directions, 3rd ed., WileyBlackwell, Chichester, UK.

Mohamed, S. 2002, 'Safety climate in construction site environments', Journal of Construction Engineering and Management, 128 (5), 375-384.

Molenaar, K., Washington, S., \& Diekmann, J. 2000, 'Structural equation model of construction contract dispute potential', Journal of Construction Engineering and Management, 126 (4), 268277.

Mullen, J.E. \& Kelloway, E.K. 2009, 'Safety leadership: A longitudinal study of the effects of transformational leadership on safety outcomes', Journal of Occupational and Organizational Psychology, 82 (2), 253-272.

Neal, A., Griffin, M.A., \& Hart, P.M. 2000, 'The impact of organizational climate on safety climate and individual behavior', Safety Science, 34 (1-3), 99-109.

Ng, S.T., Kam, P.C., \& Skitmore, R.M. 2005, 'A framework for evaluating the safety performance of construction contractors', Building and Environment, 40 (10), 1347-1355.

Ong, E.M.S. 2008, Trust, Commitment, Satisfaction and Learning in Construction Project Teams, PhD Thesis, University of New South Wales, Sydney, Australia.

Peled, A. 2000, 'Politicking for success: the missing skill', Leadership \& Organizational Development Journal, 21(1), 20-29.

Prabhakar, G.P. 2005, 'Switch leadership in projects: An empirical study reflecting the importance of transformational leadership on project success across twenty-eight nations', Project Management Journal, 36 (4), 53-60.

Reason, J. 1990, Human Error, Cambridge University Press, New York.

Robbins, S.P. \& Hunsaker, P.L. 2009, Training in Interpersonal Skills: TIPS for Managing People at Work, Pearson Prentice Hall, Upper Saddle River, NJ.

Robbins, S.P., Bergman, R., Stagg, I., \& Coulter, M. 2012, Management, 6th ed., Pearson Education Australia.

Safe Work Australia 2012, Construction Fact Sheet, http://www.safeworkaustralia.gov.au/sites/swa/about/publications/pages/fs2010constructioninfor mationsheet (Accessed: 22 August 2013).

Samson, D. \& Daft, R.L. 2009, Management, 3rd Asia Pacific ed., Cengage Learning, South Melbourne.

Schumacker, R.E. \& Lomax, R.G. 2010, A Beginner's Guide to Structural Equation Modeling, 3rd ed., Routledge, New York.

Steers, R.M. \& Porter, L.W. 1991, Motivation and Work Behavior, McGraw-Hill, New York.

Strohmeier, S. 1992, 'Development of interpersonal skills for senior project managers', International Journal of Project Management, 10 (1), 45-48.

Sunindijo, R.Y., Hadikusumo, B.H.W., \& Ogunlana, S. 2007, 'Emotional intelligence and leadership styles in construction project management', Journal of Management in Engineering, 23 (4), 166-170.

Sunindijo, R.Y. \& Zou, P.X.W. 2011, 'CHPT construct: essential skills for construction project managers', International Journal of Project Organisation and Management, 3 (2), 139-163.

Sunindijo, R Y and Zou, P X W (2013) 'The roles of emotional intelligence, interpersonal skill, and transformational leadership on improving construction safety performance', Australasian Journal of Construction Economics and Building, 13 (3) $97-113$ 
Sunindijo, R.Y. \& Zou, P.X.W. 2012, 'Political skill for developing construction safety climate', Journal of Construction Engineering and Management, 138 (5), 605-612.

Varonen, U. \& Mattila, M. 2000, 'The safety climate and its relationship to safety practices, safety of the work environment and occupational accidents in eight wood-processing companies', Accident Analysis and Prevention, 32 (6), 761-769.

Verma, V.K. 1995, The Human Aspects of Project Management: Organizing Projects for Success, Project Management Institute, Pennsylvania, USA.

Zhu, W., Chew, I.K.H., \& Spangler, W.D. 2005, 'CEO transformational leadership and organizational outcomes: The mediating role of human-capital-enhancing human resource management', The Leadership Quarterly, 16 (1), 39-52.

Zou, P.X.W. \& Sunindijo, R.Y. 2013, 'Skills for managing construction safety risks, implementing safety tasks and developing positive safety climate', Automation in Construction, 34, 92-100.

\section{Appendix A - Interpersonal skill questionnaire items}

\section{Interpersonal skill items}

1. I am good at conveying information and ideas to others (both bosses and subordinates) and making them understand of my intention.

2. I clearly explain to the team what is to be done.

3. I am good at conveying and interpreting nonverbal communication through body language and intonation.

4. I am facing difficulties in managing conflicts.

5. People see me as a good negotiator.

6. I enjoy working in a team.

7. People consider me as an effective team leader.

8. It is difficult to encourage team members to be committed to reach common goals.

9. I always establish performance goals that are challenging, but realistic.

10. I am good at using creative ways to motivate people.

11. I always recognise the team and/or individual performance.

12. I understand how to conduct a productive and effective project meeting. 